\title{
Renal function in sick very low birthweight infants: 3. Sodium, potassium, and water excretion
}

\author{
Barry H Wilkins
}

\begin{abstract}
Renal excretion of sodium, water, and potassium was measured on 434 occasions in a sample of 40 infants of 25.5-33 weeks' gestation, birth weight 720-2000 g, between the ages of 0.5 and 36 days. Water excretion varied between $1 \%$ and $30 \%$ of the glomerular filtration rate, or $15-350 \mathrm{ml} / \mathrm{kg} / \mathrm{day}$, and varied widely from day to day in individual infants. Nearly all infants became hyponatraemic before or after the first postnatal week. There were a few instances of hypernatraemia in the first week caused by high insensible water loss. There were high levels of sodium excretion up to $16 \%$ of filtered sodium, or $21 \mathrm{mmol} / \mathrm{kg} / \mathrm{day}$, in the first two postnatal weeks. Highest levels of sodium excretion were seen in the most immature infants in the first week. In most infants sodium excretion increased either in the first week or later before a subsequent decline. Potassium excretion was often high in the first week, as much as $96 \%$ of filtered potassium, or $5 \mathrm{mmol} / \mathrm{kg} / \mathrm{day}$, and is associated with early hyperkalaemia.
\end{abstract}

\section{(Arch Dis Child 1992;67:1154-61)}

Preterm newborn infants have long been known to have difficulty in maintaining sodium balance on the sodium intake provided by human milk of $1-2 \mathrm{mmol} / \mathrm{kg} / \mathrm{day}$. This is related to excessive urinary excretion of sodium, which decreases with increasing gestational and postnatal ages and has been extensively reviewed. ${ }^{1-5}$ Hyponatraemia is common $^{1-7}$ but its cause remains debated especially in the first week where water retention or sodium depletion may con-

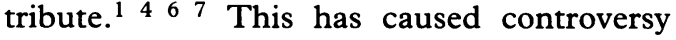
in management where some advocate sodium supplements, ${ }^{48}$ others water restriction. 67910

The question is more serious in the smallest and sickest infants in whom hyponatraemia, excessive weight loss, or conversely failure to lose weight postnatally, hypernatraemia, hyperkalaemia, uraemia, and haemodynamically significant patent ductus arteriosus (PDA) are commoner. More information on water and electrolyte excretion is therefore needed to provide guidelines for treatment in the sickest and smallest infants.

The present study was conceived because of the observation of frequent water and electrolyte complications in such infants at all ages despite sodium supplementation as advocated for healthy preterm infants. ${ }^{8}$ The purpose was to describe the various patterns of sodium, potassium, and water excretion which occur in very low birthweight infants, and to provide further information on the pathology and physiology of natriuresis in these infants.

\section{Patients and methods}

This study was part of a wider study of glomerular and tubular function in very low birthweight infants. Altogether 40 infants were chosen who could be studied in the first postnatal week, and later if possible. Gestation at birth was 25.5-33 weeks, birth weight $720-2000 \mathrm{~g}$. Studies were made up to age 3-36 days. Further clinical, experimental, and laboratory details are given in part $1 .{ }^{11} \mathrm{~A}$ total of 434 plasma/urine pairs were examined of which 120 were taken during continuous Polyfructosan-S (PF-S, Laevosan-Gesellschaft) infusion experiments by which urine flow was measured. ${ }^{12}$ In the others calculations were made from urine and plasma creatinine.

Urine flow rate (renal water excretion) was calculated from either

\section{Urine flow rate $(\mathrm{ml} / \mathrm{kg} /$ day $)=P F-S$ infusion} rate/urine PF-S concentration

or, on days when there was no PF-S infusion experiment,

Urine flow rate $(\mathrm{ml} / \mathrm{kg} /$ day $)=$ creatinine excretion rate/urine creatinine concentration

where creatinine excretion rate is that measured in that baby in the nearest PF-S infusion experiments, or $90.5 \mu \mathrm{mol} / \mathrm{kg} /$ day (the overall mean creatinine excretion rate ${ }^{13}$ ) in two infants who did not have PF-S experiments.

Excretion rate of other substances was calculated, for example sodium excretion $\left(\mathrm{E}_{\mathrm{Na}}\right)$, from

$$
\begin{aligned}
& \mathrm{E}_{\mathrm{Na}}(\mathrm{mmol} / \mathrm{kg} / \mathrm{day})=\text { urine flow rate } \times \\
& \text { urine sodium concentration. }
\end{aligned}
$$

Osmolar excretion (mosmol/kg/day) was calculated similarly from the urine osmolality.

Fractional excretion (percentage of filtered load) was calculated, for example fractional sodium excretion $\left(\mathrm{FE}_{\mathrm{Na}}\right.$ ) from

or

$$
\mathrm{FE}_{\mathrm{Na}}=\mathrm{U}_{\mathrm{Na}} / \mathrm{P}_{\mathrm{Na}} \times \mathrm{P}_{\mathrm{PF}-\mathrm{S}} / \mathrm{U}_{\mathrm{PF}-\mathrm{S}}
$$

$$
\mathrm{FE}_{\mathrm{Na}}=\mathrm{U}_{\mathrm{Na}} / \mathrm{P}_{\mathrm{Na}} \times \mathrm{P}_{\mathrm{Cr}} / \mathrm{U}_{\mathrm{Cr}} \times 1 \cdot 101
$$

where 1.101 is the mean ratio in this study between inulin and creatinine clearance, ${ }^{14}$ and corrects for tubular creatinine reabsorption. $\mathrm{U}$ and $\mathrm{P}$ represent urine and plasma concentrations. 


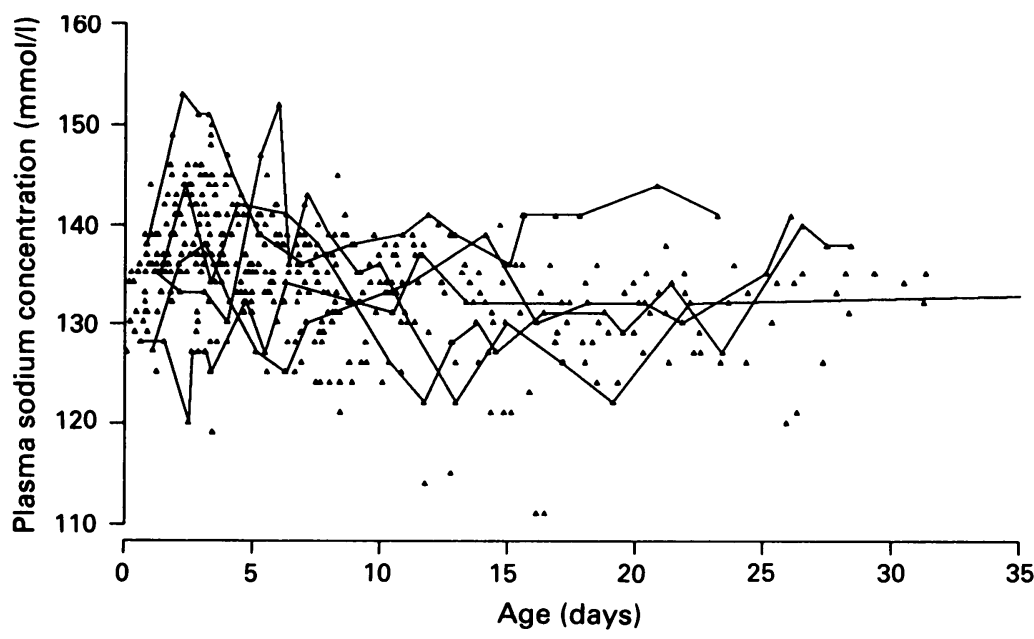

Figure 1 Plasma sodium concentrations as a function of postnatal age. Sequential points are joined for five individuals ( $n=479$ observations in 40 infants).

Fractional water excretion $\left(\mathrm{FE}_{\mathrm{Water}}\right)$ was calculated from

or

$$
\mathrm{FE}_{\mathrm{W} \text { ater }}=\mathrm{P}_{\mathrm{PF}-\mathrm{S}} / \mathrm{U}_{\mathrm{PF}-\mathrm{S}}
$$

$$
\mathrm{FE}_{\mathrm{Water}}=\mathrm{P}_{\mathrm{Cr}} / \mathrm{U}_{\mathrm{Cr}} \times 1 \cdot 101
$$

Excretion and fractional excretion rates calculated from creatinine are accurate for the individual spot urines (but may carry some imprecision because creatinine excretion rate varies up to $+32 \%{ }^{13}$ ), and it is not implied that they hold true for other urines passed on the same day. Weight rather than surface area was used because it is physiologically more appropriate in immature infants ${ }^{11}$ and more accessible in routine practice. Birth weight was used unless the baby was growing and had regained his birth weight. Factoring by a weight less than birth weight causes false over estimation of renal functions. ${ }^{11}$

Plasma sodium and potassium were measured with ion selective electrodes on a Technicon RA-1000 auto analyser. Coefficient of variation was $<1 \%$. Although the electrodes measure concentrations in plasma water, a correction to actual plasma concentration is made automatically. Small

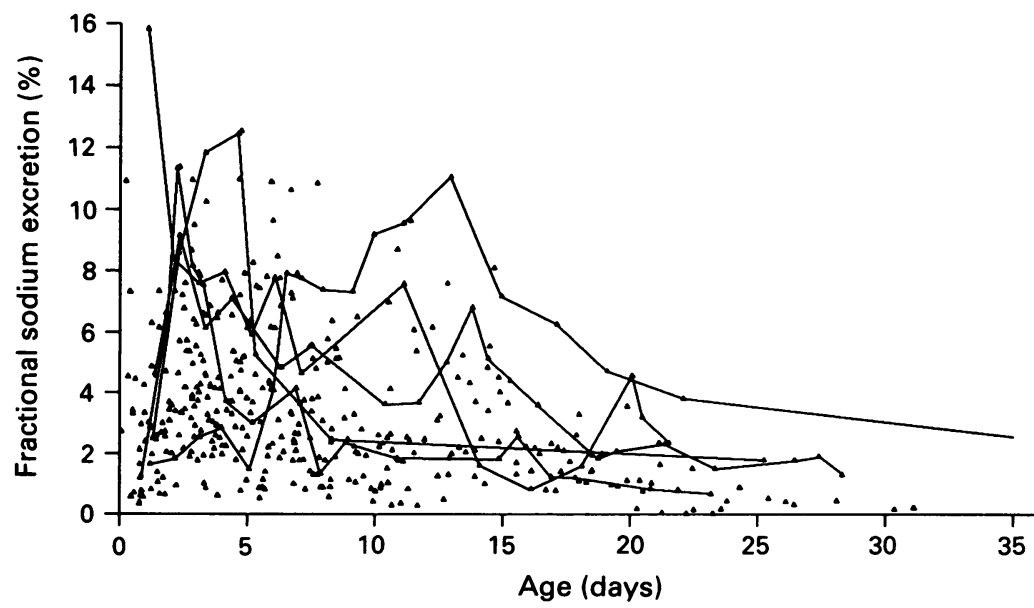

Figure 2 Fractional sodium excretion as a function of postnatal age. Sequential points are joined for five individuals. Of 432 measurements, 120 were made from $P F-S$ infusion experiments and 312 from plasma and urine creatinine. differences between the composition of adult and neonatal plasma and the $5-7 \%$ of plasma non-water can be ignored (for example in calculating fractional excretion) when we are interested in many-fold differences between subjects in quantities such as fractional sodium excretion. Urine sodium and potassium were measured by flame photometry (Instrumentation Laboratories 913). The coefficient of variation was $<1 \%$ over range $10-200 \mathrm{mmol} / \mathrm{l}$. Plasma and urine osmolalities were measured by cryoscopy (Gonotec Osmomat 030). The coefficient of variation was $<1 \%$ over range $50-1000 \mathrm{mosmol} / \mathrm{kg}$.

\section{Results}

PLASMA SODIUM

Normal plasma sodium (136-144 mmol/l) was rare especially after age 1 week (fig 1). Hypernatraemia was uncommon and confined to the first week and to infants less than 29 weeks' gestation despite early high sodium excretion. Most infants studied beyond 2 weeks were hyponatraemic, but this was also common in the first week. Many infants had an initial increase in plasma sodium, which was greater in more immature infants and always accompanied by weight loss, reflecting water balance. There was frequently a peak in plasma sodium between 2 and 4 days, occasionally later, followed by a progressive fall, the latter accompanied not by a regaining of weight but by rising or continuing sodium excretion. Late hyponatraemia beyond two weeks was often profound and prolonged (for example fig $5 \mathrm{~A}$ and $\mathrm{C}$ ). These features are illustrated in fig 1 by five infants whose sequential points are joined.

\section{SODIUM EXCRETION}

There was a wide range of fractional sodium excretion in the first two weeks (fig 2), from zero to $16 \%$. No distinction is made in this and other graphs between creatinine and PF-S derived values, for clarity and because it makes no difference to the message of the paper. There was a postnatal increase in most infants up to a peak which occurred between days 1 and 8 , at all gestations from 25-33 weeks, followed usually by a gradual decline although there was considerable fluctuation in some with second peaks. Sodium excretion $(\mathrm{mmol} / \mathrm{kg} /$ day $)$ had a very similar pattern. The height of the peak in the first week was inversely related to gestational age (fig 3) and in infants less than 28 weeks' gestation the maximum recorded sodium excretion for each baby was $10-22 \mathrm{mmol} / \mathrm{kg} /$ day. The regression slope, 1.17 has $95 \%$ confidence interval -0.69 to $-1.65, \mathrm{p}<0.0001$. Total solute (osmolar) excretion varied between 5 and 61 mosmol $/ \mathrm{kg} / \mathrm{day}$, with higher values seen in the more immature infants.

The magnitude of the early sodium excretion is such that, if continued over several days (the measurements here applied to single voidings only), there is likely to be a cumulative negative sodium balance of up to 


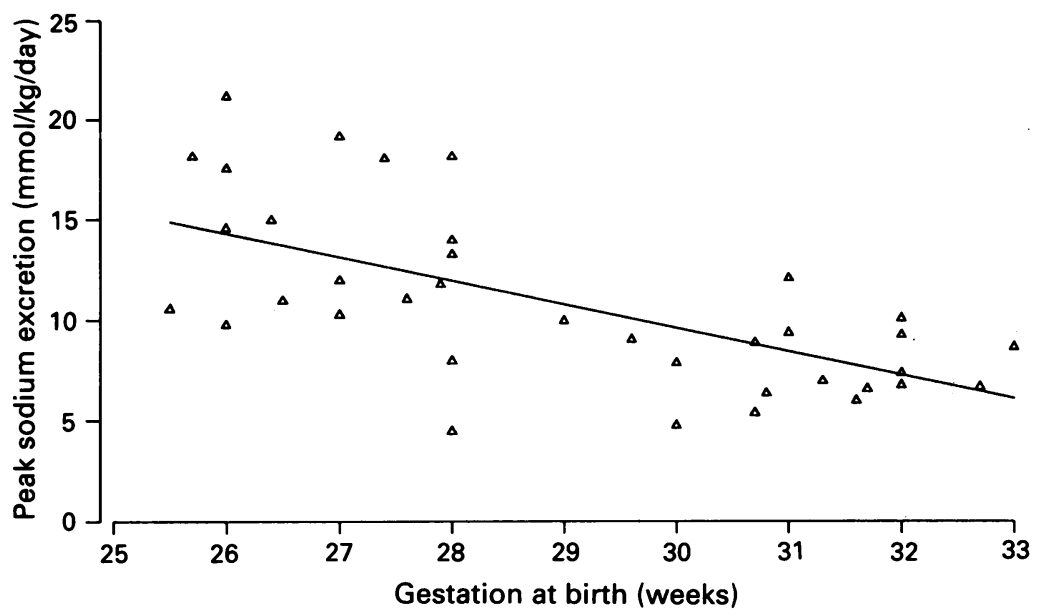

Figure 3 The peak sodium excretion during the first postnatal week as a function of gestation at birth in 38 infants. The least squares linear regression line imposed has the formula: Peak $E_{\mathrm{Na}}$ (mmol/kg/day) $=44 \cdot 6-1 \cdot 17 \times$ gestation (weeks).

$20 \mathrm{mmol} / \mathrm{kg} / \mathrm{day}$, or a fifth of the total body sodium, so it is not surprising that some infants became severely sodium depleted with weight loss of up to $23 \%$ of birth weight.

In 10 infants a large increase in sodium excretion occurred after the first week. In one case shown in fig 2 this was in a baby who had had only a modest sodium excretion in the first week and who then had a prolonged excretion of greater than $15 \mathrm{mmol} / \mathrm{kg} /$ day in the second week and was still high in the fourth week. This same infant also had early hyponatraemia, weight gain, and delayed water excretion (figs $5 \mathrm{~A}$ and 6) and a glomerular filtration rate (GFR) low in the normal range. In others a second peak occurred after the initial peak of sodium excretion. In all 10 cases this phenomenon was associated with an acute illness in the child which had the appearance of acute septicaemia. Sepsis was proved in only three infants. In most there was also late worsening of or prolongation of ventilatory failure and ventilation requirements, or the development of symptomatic PDA.

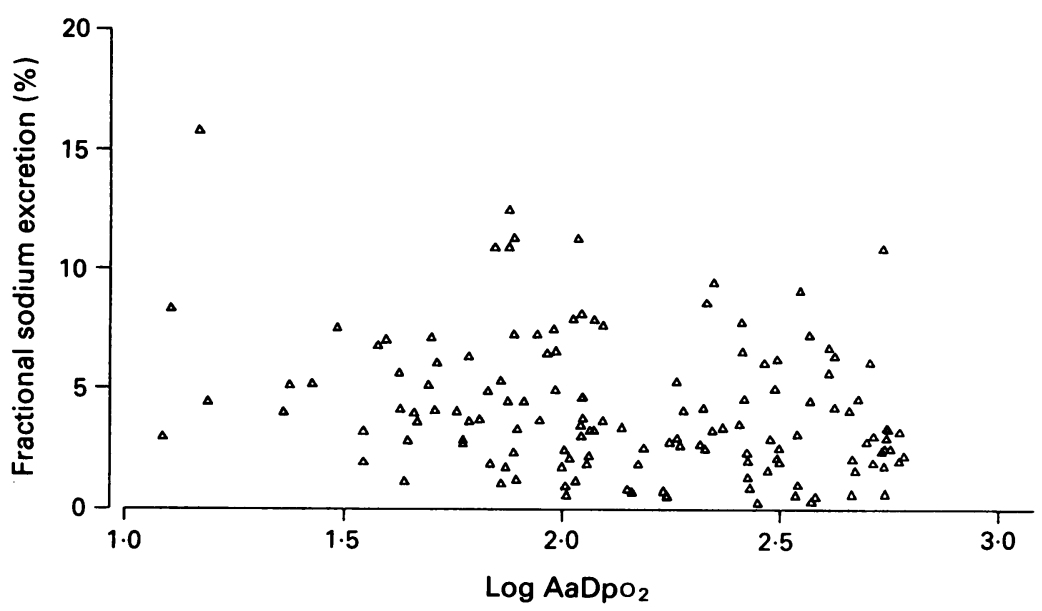

Figure 4 Fractional sodium excretion as a function of $\mathrm{AaDpO}$ in the first five days $(n=140)$. The abscissa is logarithmic. The regression formula, not shown, is: $\mathrm{FE}_{\mathrm{Na}}=8.28-1.90 \times \mathrm{AaDPo}_{2}$.
An initial investigation of the effect of respiratory disease on sodium excretion showed a weak negative relationship between sodium excretion and alveolar-arterial oxygen partial pressure difference $\left(\mathrm{AaDpO}_{2}\right)$ in the first five days, during which time most infants had a peak in their ventilatory requirement (fig 4). There was no relationship after five days. The regression slope, -1.90 has $95 \%$ confidence interval -3.00 to $-0 \cdot 80, \mathrm{p}<0.05$, but the line is not shown because it is not really appropriate when there is a mixture of cross sectional and longitudinal data. This suggests that the early peak in sodium excretion might occur as $\mathrm{AaDpO}_{2}$ is improving. ${ }^{15}$ Inspection of individual results is more interesting but shows no standard relationship. In seven infants sodium excretion increased while $\mathrm{AaDpO}_{2}$ was high or still rising, in 14 the peak sodium excretion occurred on the same day as the beginning of a sustained improvement in $\mathrm{AaDpO}_{2}$ and in nine the sodium excretion was already decreasing. Similar results were seen if the arterial:alveolar oxygen partial pressure ratio was used instead of $\mathrm{AaDpO}_{2}$.

Inspection of individual sequential results showed no overall tendency for high excretion rates to be associated with higher sodium inputs. Individual excretion and balance are plotted together with plasma sodium concentration, weight and urine flow rate in fig 5 for four infants. In most cases the 'balance' (calculated from the difference between the sodium excretion for the given urine sample and the sodium input at the same time) and excretion varied in parallel and there was only an occasional case, but never in the first week, where an increase in both excretion and negative balance were preceded by an increase in sodium input, for example in fig 5C where hyponatraemia provoked the increased sodium input.

\section{WATER EXCRETION}

Fractional water excretion varied widely at all gestations and ages, from $1 \%$ to $30 \%$ of filtered water (fig 6) or 16 to $350 \mathrm{ml} / \mathrm{kg} /$ day. The highest values were in the first two weeks. All results apply to single urine voidings and are not necessarily sustained, and indeed the six individual sequential plots (fig 6) illustrate that water excretion often varied widely from day to day when intravenous water input was constant, and there was no consistent pattern or trend.

Except in two infants, including the infant shown in fig $5 \mathrm{~A}$, who had initial weight gain and relative oliguria associated with high ventilation requirement, no relationship could be found between water excretion and oxygenation. Fractional excretion of free water ranged from $-5 \%$ to $+15 \%$ of filtered water at all levels of $\mathrm{AaDpO}_{2}$.

Two other babies had initial water retention, but rarely was there prolonged oliguria $(<50 \mathrm{ml} / \mathrm{kg} /$ day), and never prolonged polyuria ( $>200 \mathrm{ml} / \mathrm{kg} /$ day).

There was no overall relationship between water and sodium excretion. The peak of sodium excretion in the first week was sometimes 


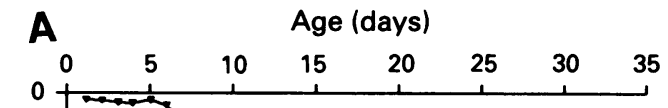

B Age (days)
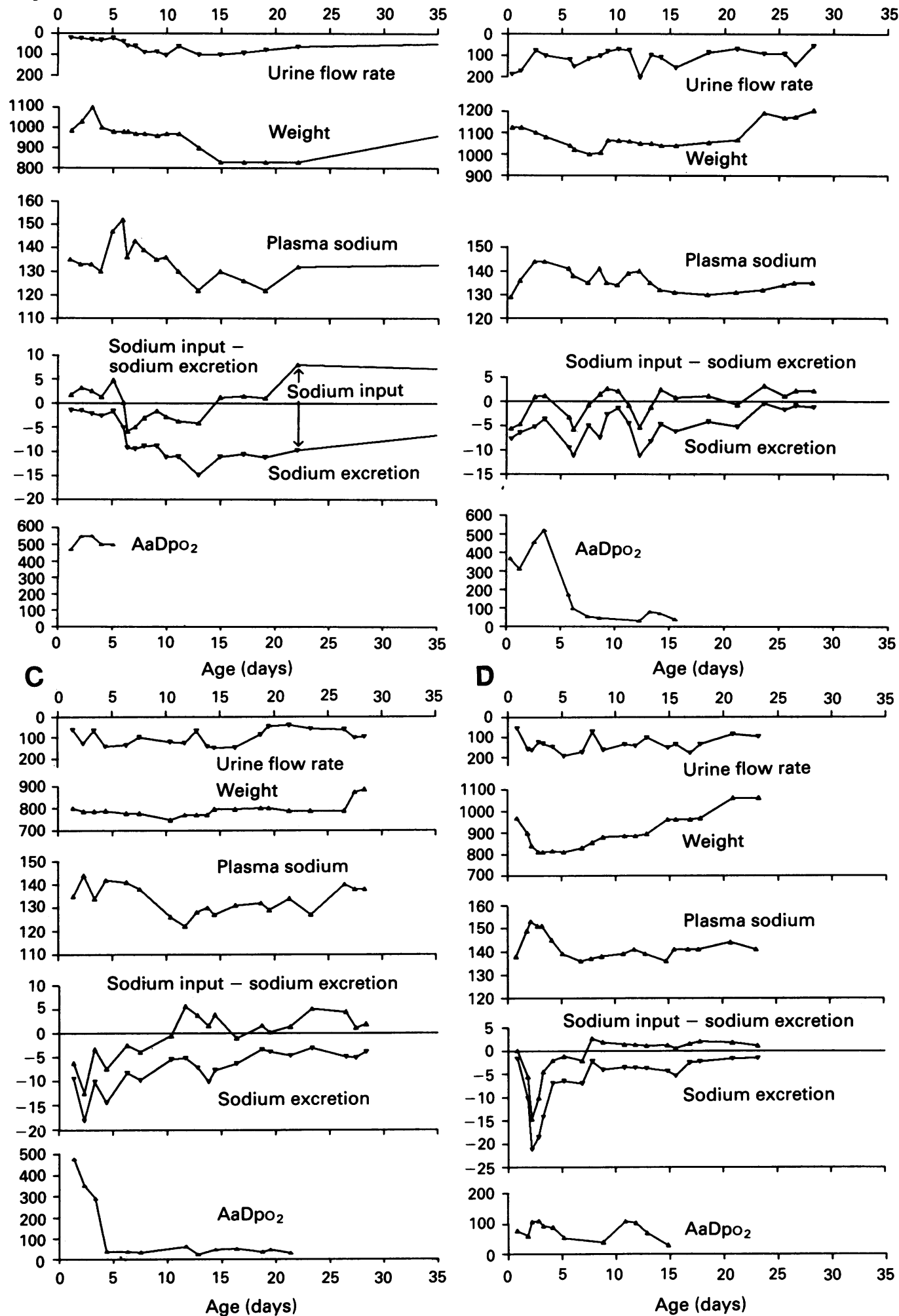

Figure $5(A)-(D)$ Details of water excretion (urine flow rate in $\mathrm{ml} / \mathrm{kg} /$ day), plasma sodium (mmoll) and sodium excretion (mmol/kg/day), and oxygenation (as $\mathrm{AaDpO}$ in $\mathrm{mm} \mathrm{Hg}$ ) as a function of postnatal age in four individuals (weight in $g$ ).

accompanied by an increasing urine flow rate but this was not usually higher than after the decline in sodium excretion. At later ages, however, a secondary increase in sodium output at times of illness was often accompanied by an increased urine flow, for example fig $5 \mathrm{~B}$ at age 12 days, suggesting that the increased solute excretion has caused an osmotic diuresis.
PLASMA POTASSIUM

Plasma potassium (fig 7) tended to be high in the first three days, especially in the 20 most immature infants less than 28 weeks' gestation and almost invariably decreased to a nadir at 2 to 6 days, increasing again thereafter illustrated by the three individuals shown. Complications did not occur. 


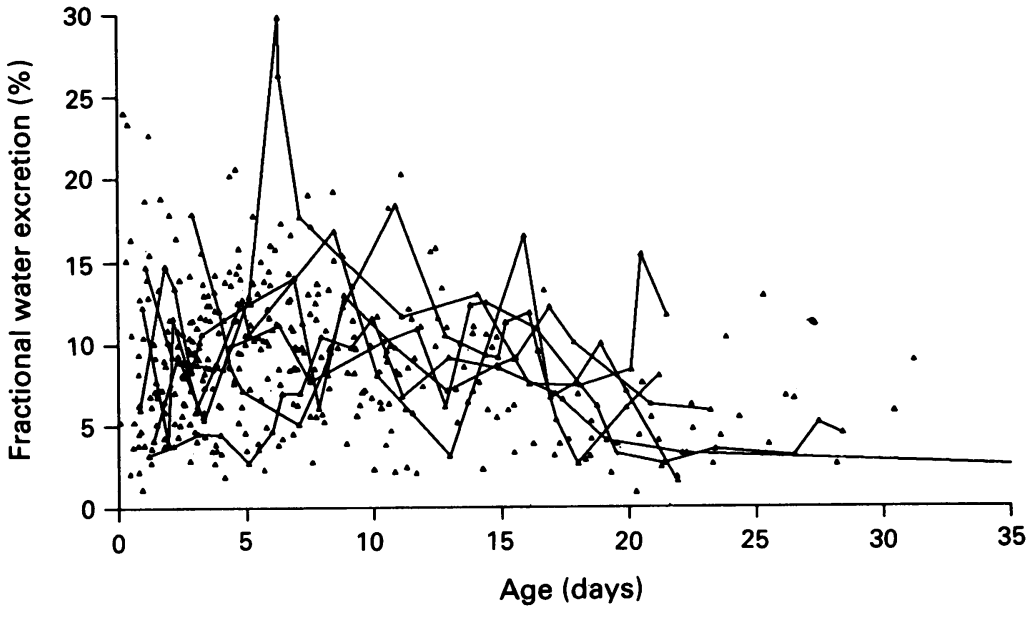

Figure 6 Fractional water excretion as a function of postnatal age. Sequential points are joined for six individuals. Of 432 measurements, 120 were made from $P F-S$ infusion experiments and 312 from plasma and urine creatinine.

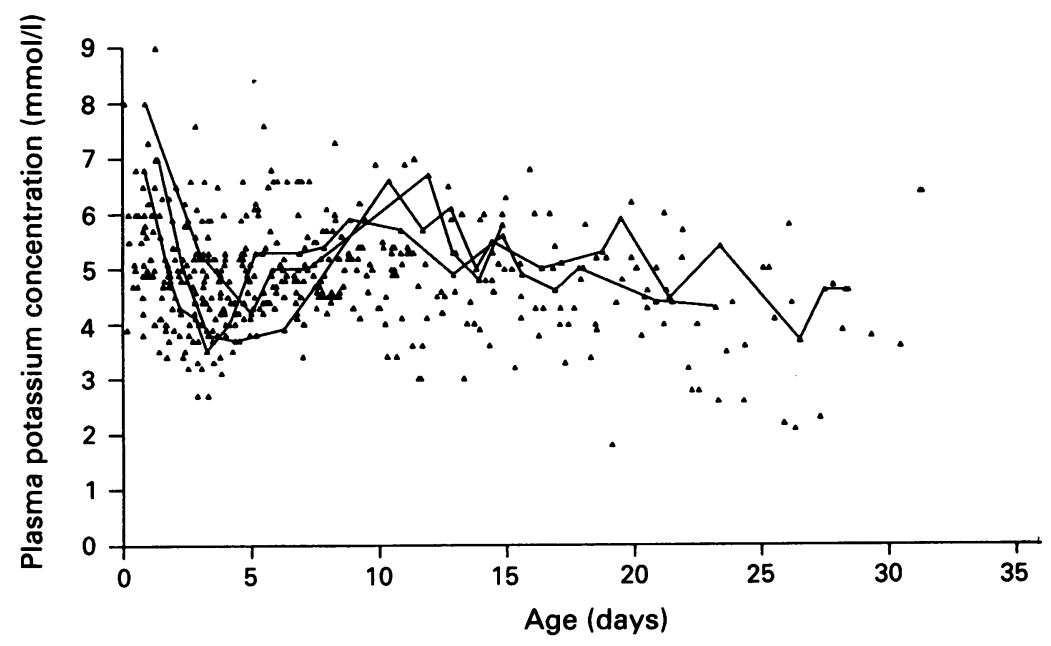

Figure 7 Plasma potassium concentration as a function of postnatal age. Sequential points are joined for three individuals ( $n=478$ observations in 41 infants).

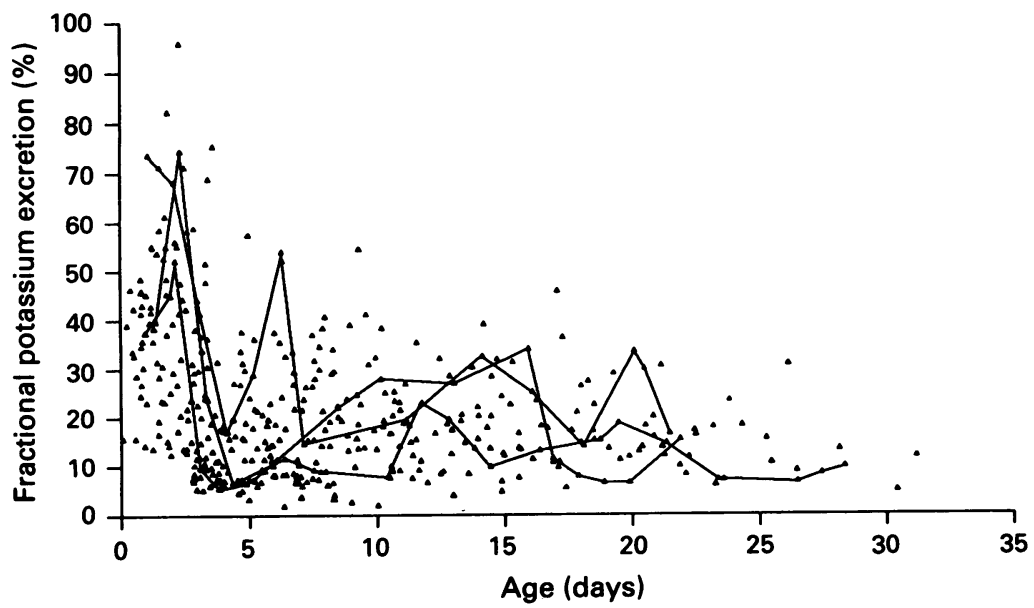

Figure 8 Fractional potassium excretion as a function of postnatal age. Sequential points are joined for three individuals. Of 431 measurements, 120 were made from PF-S infusion experiments and 311 from plasma and urine creatinine.
POTASSIUM EXCRETION

Potassium excretion paralleled plasma potassium in the first week with a peak at 1 to 3 days of up to $96 \%$ of the filtered load or 1.5 to $5.1 \mathrm{mmol} / \mathrm{kg} /$ day (figs 8 and 9 ). The latter, $5.1 \mathrm{mmol} / \mathrm{kg}$, is more than the total extracellular fluid potassium content and about a 10th of the total body potassium, and potassium was rarely administered in the first two days. Potassium excretion was highest in the most immature. The regression slope in fig 9, $-0 \cdot 283$, has $95 \%$ confidence interval -0.455 to $-0.111, \mathrm{p}<0.01$. In individual babies there was a common overall pattern of a high potassium excretion in the early postnatal period followed by a rapid decline which is then followed by a later increase to a broad peak in the second week or a little later. Potassium and sodium excretion did not necessarily mirror one another with the nadir of potassium excretion at the same time as the peak sodium excretion. Sometimes both sodium and potassium excretion increased and fell together, in others the sodium excretion remained high and fell after potassium excretion fell.

A scattergram of urine sodium:potassium (Na:K) ratio is similar to sodium excretion (fig 2) suggesting a direct relationship between sodium excretion and the urine $\mathrm{Na}: \mathrm{K}$ ratio. The correlation is very weak, however, but increased by comparing the logarithms which normalises the distributions of the two quantities $(r=0.52$ for days $1-5,95 \%$ confidence interval 0.40 to $0.62, \mathrm{p}<0.0001$, $\mathrm{n}=177$ ). In any event, normal $\mathrm{Na}: \mathrm{K}$ ratio in healthy full term infants is about 1 (the ratio of $\mathrm{Na}: \mathrm{K}$ in breast milk). In very few urine samples was it this low, the majority having a high $\mathrm{Na}: \mathrm{K}$ ratio up to 70 . This might be taken to mean that the high sodium excretion is caused by immaturity of $\mathrm{Na}: \mathrm{K}$ exchange mechanisms in the distal renal tubule. In this case, one might expect to find an adverse relationship between fractional potassium excretion and fractional sodium excretion. No such relationship was found; in fact there was a direct relationship, especially on days 2 and 3. For example, on day $3 r=0.57,95 \%$ confidence interval 0.32 to $0.75, \mathrm{p}=0.0001, \mathrm{n}=42$.

Potassium excretion correlated strongly with urea excretion on postnatal days 1, 2, and 3 but not thereafter. For example, on day 2 urea and potassium excretion had ranges $1 \cdot 5-11$ and $0 \cdot 8-4.5 \mathrm{mmol} / \mathrm{kg} /$ day respectively, and Pearson's $r$ was 0.75 (95\% confidence interval 0.57 to $0.86, \mathrm{p}=0.0001, \mathrm{n}=35$ ).

\section{Discussion}

Many studies have shown high sodium excretion with a rapid postnatal decline and a high incidence of hyponatraemia in immature infants in the first one to three weeks. ${ }^{1-7} 16-20$ Higher levels of sodium excretion have been found in the present study matched only by those of one study of very immature sick infants.

Various patterns of postnatal sodium excretion have been found. Whereas it has been previously noted that there is a rapid postnatal 


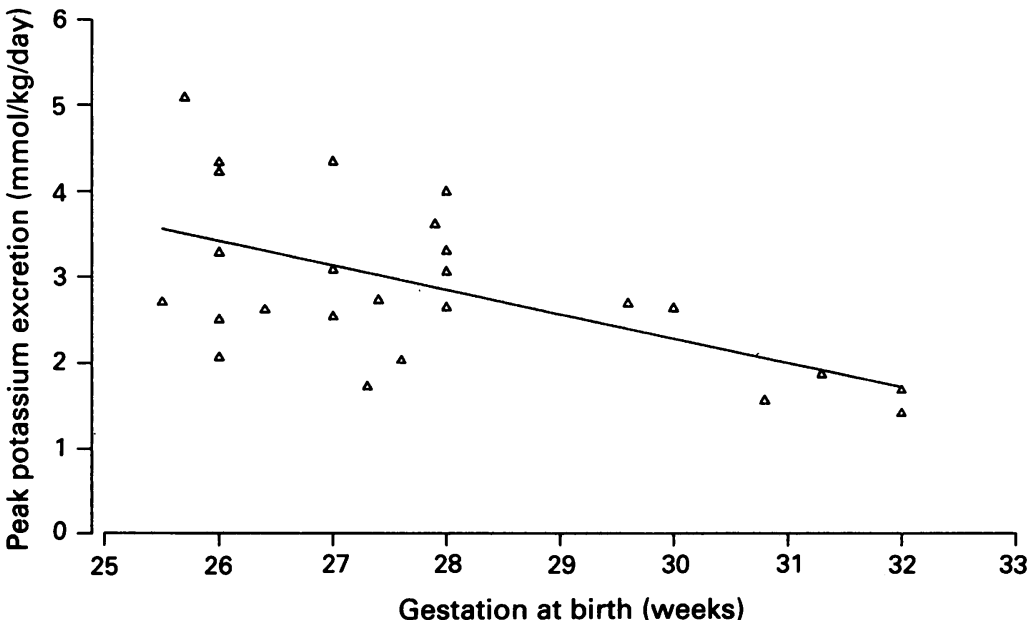

Figure 9 The peak potassium excretion in the first three postnatal days as a function of gestation at birth in 25 infants. The least squares linear regression line has the formula:

decline in the sodium excretion, ${ }^{2}$ the frequent initial increase in sodium excretion before the decline, and often a secondary increase, in the present study cannot be attributed to a universal rapid maturation of tubular function. The initial increase might be attributed to the postnatal increase in GFR from low fetal levels, thus flooding the tubules with an increasing filtered load of sodium, but it has also been shown here that GFR reaches its final level by the second day. ${ }^{11}$ It would seem that the maturation in terms of ATPase sites can be offset by functional failure, perhaps in the manner of a 'sick cell syndrome' or down regulation of $\mathrm{Na} / \mathrm{K}$ ATPase. There is no evidence here or in other studies that increased sodium excretion has resulted from higher sodium input (this is generally $<5$ $\mathrm{mmol} / \mathrm{kg} /$ day) except in a few instances later than age one week. Further studies are needed to confirm the smoothness of the day to day variation in sodium excretion.

THE CAUSE OF HYPONATRAEMIA

Hyponatraemia may be present at birth reflecting maternal hyponatraemia. The cause of subsequent hyponatraemia in the first week may include sodium wastage or water retention and each have their advocates, ${ }^{1}$ although late hyponatraemia is generally agreed to reflect sodium depletion. In the present study sodium depletion was often severe and early and with a frequent fall in plasma sodium without an increase in weight, often after hypernatraemia, this suggests that renal sodium wasting contributes. A third possibility, a generalised cell membrane $\mathrm{Na} / \mathrm{K}$ ATPase failure with decreased cell membrane gradient and intracellular sodium shift has been dismissed ${ }^{1}$ because the plasma sodium is not replaced by another cation. But extracellular and intracellular hypo-osmolality must coexist and this might be caused by either water retention or combined sodium and potassium depletion. The potassium excretion observed here (up to $5 \mathrm{mmol} / \mathrm{kg} /$ day) in the first three to four days suggests this is a possibility. Potassium excre- tion has previously been $<2 \mathrm{mmol} / \mathrm{kg} /$ day, 23520 and well infants are in positive balance. ${ }^{5} 2021$ However, ill infants may be in negative balance. $^{22}$ The non-oliguric hyperkalaemia, also observed by others, ${ }^{3} 22-25$ is associated with high renal excretion of potassium. This is attributed to a catabolic state because it is associated, as on days 1 to 3 here, with high urea excretion, ${ }^{3}$ although the latter continues for much longer in the present study. The potassium wastage may be more specifically the result of deficient or down regulated cellular $\mathrm{Na} / \mathrm{K}$ ATPase. A further study with accurate potassium balances would help to quantify potassium and sodium losses. Urine collections every four hours with 24 hour moving averages would avoid some of the inaccuracy due to incomplete and variable bladder emptying and occasional incomplete collections.

Healthy preterm infants are able to vary their water excretion according to input. ${ }^{26}$ Much of this variation in day-to-day urine volume observed here is not explained. True inappropriate antidiuretic hormone syndrome (SIADH) is probably uncommon in preterm infants, ${ }^{27}$ although it has frequently been implicated in causing hyponatraemia in neonates. ${ }^{6} 28$ Clinically inapparent volume depletion is common, so it is likely that many cases of alleged SIADH are due to physiologically appropriate rather than inappropriate antidiuretic hormone secretion. This is a most important distinction to make because in SIADH restriction of water intake is required whereas increased volume input may be required otherwise. Conversely, dehydration is not necessarily implied by a combination of high plasma urea and low urine flow. ${ }^{13}$

A possible reason for some occasions of high urine flow may be a high osmolar excretion rate; for example, if the maximum urine osmolality is 600 and the osmolar excretion rate is as high as $60 \mathrm{mosmol} / \mathrm{kg} /$ day, then a urine volume of at least $100 \mathrm{ml} / \mathrm{kg} /$ day is required in order to excrete this obligatory solute. An obligatory water, as well as solute, loss may therefore be occurring, especially when urine osmolality is not maximal.

\section{THE NATURE OF THE SODIUM WASTAGE}

The sodium depletion may be attributed to failure of proximal tubule reabsorption. ${ }^{5}$ Although the distal tubule fails to compensate 2930 distal reabsorption is probably relatively intact. ${ }^{31}$ Various animal models, mainly rat and rabbit, show a slow postnatal increase in the number of $\mathrm{Na} / \mathrm{K}$ ATPase sites after birth. ${ }^{32-37}$ This is preceded by a slow increase in the sodium permeability of individual cells and can be inhibited by chronic administration of amiloride suggesting that the development of the pump is stimulated by sodium substrate itself. This may explain the apparent acceleration of renal tubular maturation. 34-37 Marsupial pouch young, born very immature, may normally have low plasma sodium concentrations rising throughout pouch life from about $110 \mathrm{mmol} / \mathrm{l}$ to 140 mmol/1 (G Wilkes, S Thomas, $\mathrm{P}$ Janssens, 
B H Wilkins, unpublished observations), but they are unlikely to be chronically sodium depleted because they grow very fast. In the premature infant sodium depletion probably matters more than hyponatraemia itself in terms of subsequent growth. ${ }^{1}$ The fact that early and transitional milk and the milk of mothers of prematures (and marsupial milk) contains higher sodium, ${ }^{38-41}$ and that sodium supplementation promotes a more stable plasma sodium, sodium repletion and growth, 5842 are further evidence that sodium depletion is not the best state of affairs for preterm infants.

Those who advocate that this may be a physiological adaptation to the demands of the circulatory changes after birth ${ }^{79174344}$ ignore the high sodium excretion continuing after the extra cellular fluid contraction and the late increases in sodium excretion observed, presumably caused by down regulated $\mathrm{Na} / \mathrm{K}$ ATPase. Sodium and water restriction together may not lead to hyponatraemia ${ }^{10}$ but will lead to volume contraction and delayed growth. ${ }^{1}$ Sodium homoeostasis in the newborn is geared towards sodium conservation not excretion, and an expanding extracellular volume. PDA, sometimes attributed to volume ${ }^{45}$ overload and failure to contract extra cellular space, was seen in this study in infants who lost $20 \%$ of birth weight as well as in those who lost none.

Glomerulotubular balance may well be deficient $^{2} 27$ but in immature infants there is a major failure of sodium reabsorption in the proximal tubule at a degree at which glomerulotubular balance will not normally operate. This is a fine control mechanism which prevents wide fluctuations in tubular fluid delivery to the distal tubule due to small changes in GFR or proximal tubular fluid handling.

\section{NATRIURESIS AND RESPIRATORY DISEASE}

It is speculated that atrial natriuretic peptide (ANP) plays a part in the isotonic contraction of extracellular fluid in mature and immature newborns. ${ }^{15}$ 46-48 Hormones have not been measured in the present study but in several studies mean ANP concentrations are very much higher in preterm infants and may be contemporaneous with natriuresis, but not always. ${ }^{43} 464950$ This has led to the speculation that improving pulmonary perfusion causes ANP release by left atrial distension thereby causing the natriuresis associated with improving respiratory function. 1550

There are conflicting reports concerning the effect of respiratory disease. An increased fractional sodium excretion has been observed, ${ }^{51} 52$ which suggests that respiratory disease impairs tubular function. Others found no influence on the sodium excretion. ${ }^{17}$ There is usually a diuretic phase before, after, or during recovery from respiratory disease which may represent a delayed contraction of extracellular water space. ${ }^{155354}$ ANP is a hormone whose function is not just natriuresis but to protect against volume overload. Hypoxia and high pulmonary vascular resis- tance are other, non-physiological stimuli. Just as the high aldosterone concentration does not necessarily mean that it is effecting a normal physiological response, ${ }^{5} 20$ so also it would be incorrect to assume that high ANP levels are entirely physiological.

\section{IMPLICATIONS FOR TREATMENT}

We do not know in individuals how much of the early and late sodium loss should be replaced nor to what extent the variable postnatal weight loss is a necessary adaptation to the change in circulatory anatomy. There is unlikely to be an ideal weight loss for all infants. Advocators of sodium and water restriction, 910 and therefore volume depletion, say that water excess is a disadvantage as a rule. Although sodium supplementation to $5 \mathrm{mmol} / \mathrm{kg} /$ day improves weight gain in some infants, ${ }^{8}$ we now need a trial to compare a policy of volume depletion with one of volume repletion, and to determine whether early sodium replacement in sick very low birthweight infants makes any difference to weight gain, to the incidence of PDA and other complications, to duration of hospitalisation or to neurodevelopmental outcome. A three armed study would be needed comparing (1) low water input and sodium supplementation only according to evidence of sodium depletion, ${ }^{10}$ (2) high water input with elective early sodium supplementation to 3,4 , or $5 \mathrm{mmol} /$ $\mathrm{kg} /$ day, ${ }^{8}$ and (3) high water input with prospective sodium replacement according to measured losses.

This work was funded by the Children Nationwide Medical Research Fund, and the Southmead Research Foundation Southmead Hospital, Bristol. The author is grateful to Mrs N Kingston and Mrs M Williams for performing some of the laboratory work, to Dr B Speidel, Dr P Fleming, and Professor P Dunn for allowing their patients to be studied, Dr T Chambers for continual encouragement, and Dr J Midgley for inspiration in the final stages of writing.

1 Haycock GB, Aperia A. Salt and the newborn kidney. Pediatr Nephrol 1991;5:65-70.

2 Al-Dahhan J, Haycock GB, Chantler C, Stimmler I Sodium homeostasis in term and preterm neonates. I. Renal aspects. Arch Dis Child 1983;58:335-42.

3 Aiken CGA, Sherwood RA, Kenney IJ, Furnell M, Lenney W. Mineral balance studies in sick preterm intravenously ed infants during the first week after birth. A guide to fluid therapy. Acta Paediatr Scand 1989; Suppl 355:1-59.

4 Engelke SC, Shah BL, Vasan U, Raye JR. Sodium balance in very low birthweight infants. $\mathcal{f}$ Pediatr 1987;93: $837-41$

5 Sulyok E, Németh M, Tenyi I, Csaba IF, Varga L, Varga F. Relationship between the postnatal development of the renin-angiotensin-aldosterone system and the electrolyte and acid-base status in the sodium chloride supplemented premature infant. Acta Pediatr Acad Sci Hung 1981; 22:109-21.

6 Rees L, Brook CGD, Shaw JCL, Forsling ML. Hyponatraemia in the first week of life in pre-term infants. Part
1. Arginine vasopressin secretion. Arch Dis Child 1984; 1. Arginine

7 Rees L, Brook CGD, Shaw JCL, Forsling ML Hyponatraemia in the first week of life in pre-term infants. Part 2. Sodium and water balance. Arch Dis Child 1984;59:423-9.

8 Al-Dahhan J, Haycock GB, Nichol B, Chantler C, Stimmler L. Sodium homeostasis in term and pre-term neonates. III. Effect of salt supplementation. Arch Dis Child 1984;59:945-50.

9 Arant BS. Fluid therapy in the neonate-concepts in transition. $\mathcal{F}$ Pediatr 1982;101:387-98.

10 Lorenz JM, Kleinman LI, Kotagal UR, Reller MD. Water balance in very low birthweight infants: relationship to water and sodium intake and effect on outcome. $\mathcal{F}$ Pediat 1982;101:423-32.

11 Wilkins BH. Renal function in sick very low birthweight infants: 1. glomerular filtration rate. Arch Dis Child 1992; 67:1140-5. 
12 Wilkins BH. Renal aspects of sodium and water homeostasis in very low birth weight newborn infants. Cambridge: University of Cambridge, UK, 1989. (Dissertation.)

13 Wilkins BH. Renal function in sick very low birthweight infants: 2. creatinine and urea excretion. Arch Dis Child 1992;67:1146-53.

14 Wilkins BH. A reappraisal of the measurement of glomerular filtration rate in pre-term infants. Pediatr Nephrol 1992;6:323-7.

15 Modi N, Hutton JL. The influence of postnatal respiratory adaptation on sodium handling in preterm neonates. Early Hum Dev 1990;21:11-20.

16 Siegel SR, Oh W. Renal function as a marker of human fetal maturation. Acta Paediatr Scand 1976; 65:481-5.

17 Ross B, Cowett RM, Oh W. Renal functions of low birthweight infants during the first two months of life. Pediatr weight infants during

18 Honour JW, Valman HB, Shackleton CHL. Aldosterone and sodium homeostasis in preterm infants. Acta Paediat Scand 1977;66:103-9.

19 Sulyok E, Varga F, Györy E, Jobst K, Csaba IF. On the mechanism of renal sodium handling in newborn infants. Biol Neonate 1980;37:75-9.

20 Aperia A, Broberger O, Herin P, Zetterström R. Sodium excretion in relation to sodium intake and aldosterone excretion in newborm pre-term and full-term infants. Acta Paediatr Scand 1979;68:813-7.

21 Engle WD, Magness RR, Faucher DJ, Arant BS, Rosenfeld CR. Sodium balance in the growing preterm infant. Pediatr Res 1985;19:376a.

22 Engle WD, Arant BS. Urinary potassium excretion in the critically ill neonate. Pediatrics 1984;74:259-64.

23 Gruskay J, Costarino AT, Polin RA, Baumgart S. Nonoliguric hyperkalemia in the premature infant weighing oliguric hyperkalemia in the premature infant

24 Shortland D, Trounce JQ, Levene MI. Hyperkalaemia, cardiac arrhythmias, and cerebral lesions in high risk neonates. Arch Dis Child 1987;62:1139-43.

25 Brion LP, Schwartz GJ, Campbell D, Fleischman AR Early hyperkalaemia in very low birthweight infants in the absence of oliguria. Arch Dis Child 1989;64:270-82.

26 Coulthard MG, Hey EN. Effect of varying water intake on renal function in healthy preterm babies. Arch Dis Child $1985 ; 60: 614-20$

27 Judd BA, Haycock GB, Dalton N, Chantler C. Hyponatraemia in premature babies and following surgery in older children. Acta Paediatr Scand 1987;76:385-93.

28 Weinberg JA, Weitzman RE, Zakauddin S, Leake RD. Inappropriate secretion of antidiuretic hormone in a preInappropriate secretion of antidiuretic

29 Rodriguez-Soriano J, Vallo A, Oliveros R, Castillo G. Renal handling of sodium in premature and full-term Renal handling of sodium in premature and full-term neonates: a study using clearance me

30 Arant BS. Distal tubular sodium handling in human neonates: clearance studies. Contrib Nephrol 1988;67 130-7.

31 Elinder G, Aperia A. Effective aldosterone blocking of distal sodium absorption during development. VIth International Symposium of Pediatric Nephrology (International Pediatric Nephrology Association) Hanover, 1983, abstract No 179.

32 Fukuda Y, Larson S, Celsi G, Lechene C, Aperia A. Use of experimental models to study the development of renal function. Biol Neonate 1988;53:197-200.

33 Schmidt U, Horster M. Na-K-activated ATPase: activity maturation in rabbit nephron segments dissected in vitro. Am $\mathcal{f}$ Physiol 1977;233:F55-60.
34 Aperia A, Larsson L, Zetterström R. Hormonal induction of Na-K-ATPase in developing proximal tubule cells. $\mathrm{Am}$ f Physiol 1981;241:F356-60.

35 Schwartz G, Evans AP. Development of solute transport in rabbit proximal tubule. III. Na-K-ATPase activity. $A m \mathcal{F}$ Physiol 1984;246:F845-52.

36 Larsson L, Horster $M$. Ultrastructure and net fluid transport in isolated perfused developing proximal tubules. fournal of Ultrastructural Research 1976;54:276-85.

37 Larsson SH, Rane S, Fukuda Y, Aperia A, Lechene C. Changes in $\mathrm{Na}$ influx precedes postnatal increase in $\mathrm{Na}, \mathrm{K}$-ATPase activity in rat renal proximal tubular cells. Acta Physiol Scand 1990;138:99-100.

38 Chessex P, Reichman B, Verellen G, et al. Quality of growth in premature infants fed their own mothers' milk. growth in premature infants

39 Gross SJ. Growth and biochemical response of preterm infants fed human milk or modified infant formula. infants fed human milk or mod
$N$ Engl f Med 1983;308:237-41.

40 Schanler RJ, Oh W. Composition of breast milk obtained from mothers of premature infants as compared to milk obtained from donors. $\mathcal{f}$ Pediatr 1980;96:679-81.

41 Aperia A, Broberger O, Herin P, Zetterström R. Sal content in human breast milk during the first three weeks after delivery. Acta Paediatr Scand 1979;68: 441-2.

42 Ekblad H, Kero P, Takala J, Korvenranta H, Välimäki I. Water, sodium and acid-base balance in premature
infants: therapeutical aspects. Acta Paediatr Scand 1987; 76:47-53.

43 Tulassay T, Rascher W, Seyberth HW, Laing RE, Tóth M, Sulyok E. Role of atrial natriuretic peptide in sodium homeostasis in premature infants. F Pediatr 1986;109: homeostasi

44 Arant BS. Non renal factors influencing renal function. Clin Perinatol 1981;8:225-40.

45 Bauer K, Bovermann G, Roithmaier A, Götz M, Prölss A Versmold HT. Body composition, nutrition, and fluid balance during the first two weeks of life in preterm neonates weighing less than 1500 grams. F Pediatr 1991 118:615-20.

46 Tulassay T, Seri I, Rascher W. Atrial natriuretic peptide and extracellular volume contraction after birth. Acta Paediatr Scand 1987;76:444-6.

47 Bierd TM, Kattwinkel J, Chevalier RL, et al. Interrelationship of atrial natriuretic peptide, atrial volume, and renal function in premature infants. $\mathcal{F}$ Pediatr 1990 116:753-9.

48 Shaffer SG, Bradt SK, Hall RT. Postnatal changes in total body water and extracellular fluid volume in preterm infants with RDS. F Pediatr 1986;109:509-14.

49 Koiima T, Hirata Y, Fukuda Y, Iwase S, Kobayashia Y. Plasma atrial natriuretic peptide and spontaneous diuresis in sick neonates. Arch Dis Child 1987;62:667-70.

50 Shaffer SG, Geer PG, Goetz KL. Elevated atrial natriuretic factor in neonates with respiratory distress syndrome f Pediatr 1986;109: 1028-33.

51 Guignard J-P, Torrado A, Mazouni SM, Gautier E. Renal function in respiratory distress syndrome f Pediatr 1976;88:845-50.

52 Siegel SR, Fisher DA, Oh W. Renal function and serum aldosterone levels in infants with respiratory distress syndrome. F Pediatr 1973;83:854-8

53 Heaf DP, Belik J, Spitzer AR, Gewitz MH, Fox WW. Changes in pulmonary function during the diuretic phase of respiratory distress syndrome. $\mathcal{F}$ Pediatr 1982;101:103-7.

54 Engle WD, Arant BS, Wiriyathian S, Rosenfeld CR Diuresis and respiratory distress syndrome: physiologic mechanisms and therapeutic implications. $f$ Pediatr 1983 102:91-7. 